\title{
Capital Structure and Profitability of Commercial Banks in Nepal
}

\author{
Sahadev Bhatt ${ }^{1}$, Dr. Swati Jain ${ }^{2}$ \\ ${ }^{1} \mathrm{PhD}$ Scholar, School of Management, Poornima University, Jaipur, India \\ ${ }^{2}$ Associate Professor, School of Management, Poornima University, Jaipur, India
}

\begin{abstract}
This study seeks to examine the relationship between the capital structure and the profitability of commercial Banks in Nepal. In this connection, 18 Nepalese commercial banks were selected as study samples and their financial data were gathered from NRB BI Statistics and Bank Supervision Report for the period of 2010-2019. Return on Equity was used as indicator of profitability while short term debt, long term debt, deposits and total debt to assets ratio were used as a proxy of capital structure along with the control variables of bank size and assets growth. Results showed that more than 40 percent bank profitability measured by return on equity is predicted by the explanatory -capital structure variables. It is also revealed that return on equity is insignificantly positively related with long term debt and deposits whereas it is insignificant negative with short term debt and total debt. In all regression models, profitability is significantly positively related with banks size indicating that larger the size of the bank, higher is the return for shareholders.
\end{abstract}

Key words: Capital structure, Banks, Leverage, Profitability

\section{BACKGROUND}

Capital structure refers to the combination of debt and equity which a firm uses to finance its long-term operations. Capital in this context refers to the permanent or long-term financing arrangement of the firm. It is the aggregation of items appearing on the liability side of the balance sheet minus current liabilities (Khan \& Jain, 1997). Capital structure decision is crucial for any business firm to maximize the value of shareholders as it supposed to affect the firm's ability to deal with competitive environment. It is an important issue for the business managers today to choose the optimum combination of debt and equity to achieve value maximization by reducing the financing cost. Thus, theoretically capital stricture can play an important role in firm performance and financial stability of the economic system. Its influence on firm performance can be explained in various ways. Debt would improve profitability as the interests paid on debt are tax deductible and leverages the profits of the shareholders. Liabilities also could add operating pressure of managers so that they would take active interest in corporate operations and reduce in-service consumptions (Grossman, and Hart, 1983). Furthermore, capital structure can affect market decisions by signaling (Ross, 1977), for debt financing would pass investors active signals and it indicates better quality of assets. So operating performance is passively relative to debt ratio. In addition, based on pecking order theory, profitability is negatively relative to book value financial leverage ratio owing tohigh cost of equity financing (Myers and Majluf, 1984). When profits retained within the enterprise can't meet the need of investment, debt scale would increase quickly in parallel to the continuous growth of investment scale (Wang, 2010). Capital structure is the matter of great controversy and attention of finance academicians since the publication of seminal paper of Modigliani and Miller hereafter MM (1958). Since the MM's irrelevance theory of capital structure, a lot of literature has been explored in the field of capital structure. However, the dilemma and controversy is still going even after emergence of modern capital structure theories.

There is no doubt that the banking sector plays a significant role in the economical development of any country. Therefore performance of commercial bank is crucial not only for the value maximization for their shareholders but also for the overall financial health make-up of a nation. Banks should choose and adjust their strategic financing mix in order to maximize the value and ensure that their operation are not either highly geared or too lowly geared in order to achieve optimal capital structure.

Since Nepalese commercial banks are not exception of achieving value maximization and risk reduction, this study focuses in identifying the relationship of capital structure with the profitability. In Nepal number of studies has been conducted to examine the determinants of capital structure of different corporations; however none of these are specially directed toward the listed commercial banks in Nepal. This study aimed at contribution the debate on capital structure and bank's profitability in terms of return on equity (ROE).This study is aimed to helpful to identify the potential problems in performance/ profitability and 
capital structure of highly complex and competitive banking sector. The finding of this study will be beneficial in selecting the capital structure to achieve the optimum level of bank's profitability.

\subsection{Statement of Problem}

Banking sector differentiates itself from other sectors as its major role is to generate economic welfare through lending, borrowing and mobilization of funds. They are simultaneously firm, financial intermediaries and highly regulated entities. The nature of incentives induced by regulatory jurisdiction determines a unique interaction between bank's capital and its behavior. The capital structure decision becomes more vital for banks because the consequences of bank failure are more disastrous than the failure of other non-financial firm. Buser, at. el. (1981) argued that the capital structure decision of a bank is similar to that of non-financial firm. Although there are considerable inter industry differences in the capital structure of firms due to the unique nature of each industry's business. Most of the studies conducted abroad found a negative relationship between profitability and leverage. Titman and Wessels (1988) concluded that firm with high profit level would maintain relatively lower debt levels since they can obtain funds from plowing back profit. Furthermore Similarly, Kester (1986) found a significant negative relation between profitability and debt/asset ratios. Rajan and Zingale (1995) also confirmed a significant negative correlation between profitability and leverage in their study. However, some other researchers have concluded that the positive relationship between profitability and capital structure. Taub (1975), in a regression analysis of four profitability metrics against debt ratios found significantly positive association between debt and profitability. Abor (2005) also found a significantly positive relationship between total debt and profitability.

From ongoing research and literature it is clear that the relationship between capital structure and profitability is not conclusive and requires more empirical study especially in the context of Nepal where none of the study has been yet done in this regard. Therefore the problem of this research is to study the how the capital structure affect the bank's profitability in Nepal?

\subsection{Objectives of the Study}

The objectives set forth for this study are:

- To find the impact of capital structure on profitability.

- To find an optimal capital structure that would be associated with the best performance.

- To find the relationship of capital structure with profitability of listed commercial banks of Nepal.

\subsection{Review of Literature}

Capital structure refers to the combination of debt and equity which a firm uses to finance its long-term operations. Capital in this context refers to the permanent or long-term financing arrangement of the firm. It is the aggregation of items appearing on the liability side of the balance sheet minus current liabilities. Capital structure decision is crucial for any business firm to maximize the value of shareholders and also affects the firm's ability to deal with competitive environment. It is an important issue for the business managers today to choose the optimum combination of debt and equity to achieve value maximization by reducing the financing cost.

The capital structure theory traced back to Hicks (1946) "Value and Capital". In 1952 American economist Durante divided the capital structure's researches in to three kinds: net income theory, net operating income theory and the traditional theory between them. But the study of modern capital structure theory is started in 1958 with the seminal paper presented by Franco Modigliani and Merton Miller. They demonstrated that in a perfect market hypotheses and no tax world the capital structure is irrelevance. It serves as a starting point to search for factors that influences the firm's capital structure decisions. As a matter of theory, capital structure irrelevance can be proved under a range of circumstances. There are two fundamentally different types of capital irrelevancy. The classic arbitrage -based irrelevance proposition provide setting in which arbitrage of investors keep the value of the firm independent of its leverage. In addition to the original MM paper, important contributions include Hirshleifer (1966) and Stiglitz (1969). The second irrelevance proposition conclude that given a firm's investment policy the dividend payout it chooses to follow will affect neither the current price if its shares nor the total return to its shareholders (Modigliani and Miller, 1963).

Another school of thought holds the view that financing choice reflects an attempt by corporate managers to balance tax shield of greater debt against potential large cost of financial distress arising from under investment. However excessive debt can lead financial distress and lower leverage can lead reduction in profitability (Barclay and Smith, 2005). The choice of capital structure and its resultant optimal risk exposure is very paramount in economic performance of every business firm. This is because the choice of capital structure should ultimately result in the growth in the value of investment made in the various categories of investors particularly equity shareholders (Watson and Head, 2007).

Various authors tried to explain the effects of capital structure (Leverage) on firm profitability that fetched inconclusive results. However, empirical evidence from some previous studies seems to be consistent with the pecking order theory. There is a long list of studies that found a negative relationship between profitability and leverage. Amidu (2007) investigated the determinants of capital structure of banks in Ghana and found a significantly negative relation between total debt and profitability. Hall et al. (2004), Caesar and Holmes (2003) and Najjar and Petrov (2011) who all worked on the insurance industry established 
that a negative relationship between age of firms and both total-term debt and short-term debt ratios. Graham (2000) argued that big and profitable companies tend to use low debt levels. Fama and French (1998) advocated a negative relationship between leverage and profitability because debt does not necessarily provide tax benefits as well as high leverage may generate agency problems among shareholders and debt holders. Rajan and Zingales (1995) set a significantly negative correlation between profitability and leverage in their study. Titman and Wessels (1988) argued that, all things being equal, firms with high profit levels would maintain relatively lower debt levels since they can realize such funds from internal sources. Similarly, Furthermore, Kester (1986) found a significantly negative relation between profitability and debt/asset ratios.

There are also many empirical works against the pecking order theory. Many authors observed a positive relationship between profitability and debt levels in their studies. Abor (2005) has reported a significantly positive relationship between the ratio of short-term debt to total assets and profitability but a negative association between the ratio of long term debt to total assets and profitability. Petersen and Rajan (1994a), and Ooi (1999) found a significantly positive association between profitability and debt ratios in a study and argued that profitable firms are more attractive to financial institutions as lending prospects.

The earlier capital structure researches by Nepalese researchers include Shrestha (1985) observed that there is low capital gearing and even unbalance pattern of capital structure in Public Enterprises in Nepal. Pradhan \& Ang (1994), a study of 78 major enterprises observed that the working capital function was most important followed by capital structure decision function and the agency relation function was least important. KC (1994) in his study of 37 large and medium size firm in Nepal found significant positive relationship of long-term debt with growth, assets structure and age of incorporation. Baral (2004) showed that size, growth rate and earning rate are statistically significant determinants of capital structure of the listed companies. Gajurel (2005) in his study of capital structure pattern and its determinants for a panel of 20 non financial firm listed in NEPSE, by using de-compositional analysis, properties of portfolio analysis, econometric analysis and opinion survey of managers, it is found that Nepalese firms are highly levered, however the long-term debt ratio is significantly low. Asset structure and size are observed positively related to leverage whereas liquidity, risk, growth, non-debt tax shield are negatively related to leverage.

None of these studies examine capital structure and its influence on firm's profitability in banking sector of Nepal. Therefore this study is aimed at contributing to the debate on capital structure by examining the relationship between capital structure and bank's profitability in term of return on equity.

\subsection{Hypotheses of the Study}

The hypotheses for the study are formulated as follows:

$\mathrm{H}_{1}$ : There is no relationship between short-term debts to total assets return on equity.

$\mathrm{H}_{2}$ : There is no relationship between long-term debt to total assets and return on equity.

$\mathrm{H}_{3}$ : There is no relationship between total debt to total assets and return on equity.

$\mathrm{H}_{4}$ : There is no relationship between deposit to total assets and return on equity.

\subsection{Relevancy of the Study}

Since the researcher has not found any study in capital structure and profitability of commercial bank in Nepal therefore this study is perhaps the first of its kind in Nepal that shows the relationship of capital structure with bank's profitability, so the study is expected to be equally beneficial for bankers, policymakers, regulators and researchers. Moreover, the study will be beneficial for the bankers to improve the performance and allocate the resources in a manner that would actually improve the profitability.

\section{METHODOLOGY}

\subsection{Universe of the Study}

The universe of this study will consist of all commercial bank in Nepal. There are 28 commercial banks that established and operating in Nepal. So the universe of this study is 28 commercial banks licensed by Nepal Ratsra Bank - the central bank of Nepal.

\subsection{The Sample and Sampling design}

Saunders et al. (2007) point out that the larger the sample size, lower the likely error in generalizing the population. Therefore, a sample of 18 commercial banks are selected which represent more than 60 percent of total population. The samples are selected on the basis of purposive sampling technique.

\subsection{Data Collection Method}

The study uses the secondary data of 10 years obtained from the Banks and Financial Statistics and Bank Supervision Report published by Nepal Rastra Bank from 2010 to 2019.

\subsection{Variables and Measures}

There are three groups of variables have been used in the study. These are dependent, independent and control variables as presented in Table 2.1. 
"Capital Structure and Profitability of Commercial Banks in Nepal"

Table 2.1 Variables used in the Study

\begin{tabular}{|l|l|l|}
\hline Category & Variables & Measurement \\
\hline Dependent Variables & Return on Equity & Net Income/Shareholders Equity \\
\hline \multirow{4}{*}{ Independent Variables } & Short Term debt Ratio (STDR) & Short Term Debt/Shareholders Equity \\
\cline { 2 - 3 } & Long Term Debt Ratio (LTDR) & Long Term Debt/Total Assets \\
\cline { 2 - 3 } & Deposit Ratio (DR) & Deposits / Total Assets \\
\cline { 2 - 3 } & Total Debt Ratio (TDR) & Total debt/ Total Assets \\
\hline \multirow{2}{*}{ Control Variables } & Size of the Bank (SIZE) & Log of Total Assets \\
\cline { 2 - 3 } & Assets Growth (AG) & Ending Assets - Beginning Assets / Beginning Assets \\
\hline
\end{tabular}

\subsection{Data Analyzing Model}

The purpose of this research is to study the relationship between capital structure and profitability of the commercial banks therefore quantitative method is used in order to make the results successful. Secondary data is analyzed using quantitative method of linear regression using dependent and independent along with the control variables to measure the relationship of profitability and capital structure. Both descriptive and inferential statistics are used to summarize and to answer the research problem. The t-test is used to test the significance of the model at 5\% level of significance. The following regression models (Abor, 2005, Gill, 2011 and Shubita, 2012) are estimated:-

1. $R O E_{i t}=\beta_{0}+\beta_{1} S T D R_{i t}+\beta_{2}$ Size $_{i t}+\beta 3 A G_{i t}+e_{i t}$

2. $R O E_{i t}=\alpha_{0}+\alpha_{1} L T D R_{i t}+\alpha_{2}$ Size $_{i t}+\alpha_{3} A G_{i t}+e_{i t}$

3. $R O E_{i t}=\lambda_{0}+\lambda_{1} D R_{i t}+\lambda_{2} S_{i z e_{i t}}+\lambda_{3} A G_{i t}+e_{i t}$

4. $R O E_{i t}=\pi_{0}+\pi_{1} T D R_{i t}+\pi_{2}$ Size $_{i t}+\pi_{3} A G_{i t}+e_{i t}$

Where:

$R O E_{i t}=$ Return on equity of bank $i$ at time $t$

$S T D R_{i t}=$ Short Term debt Ratio of bank $i$ at time $t$

$L T D R_{i t}=$ Long Term Debt Ratio of bank $i$ at time $t$

$D R_{i t}=$ Deposit Ratio of bank $i$ at time $t$

$T D R_{i t}=$ Total Debt Ratio of bank $i$ at time $t$

$\beta_{0}, \alpha_{0}, \lambda_{0}$ and $\pi_{0}$ : The intercept of equation 1,2,3 and 4 .

$\beta, \alpha, \lambda$ and $\pi$ : Coefficients for independent variables i.e. Rate of change in dependent variable per unit change in independent variable.

$i$ : firm

$t:$ time $=1,2, \ldots \ldots, 10$ years.

eit $=$ Error term.

\subsection{Outliers, Multicolinearity and Autocorrelation Problem}

Cook's distance, Di, has been used in regression analysis to find influential outliers in a set of predictor variables. A general rule of thumb is that observations with a Cook's Distance of more than 1 indicate an influential value or outlier. Multicolinearity problem which affect the model power and its ability in explaining the results have been checked by Variance Inflation Factor (VIF). As a rule, if VIF factors are less than 5, there is no Multicolinearity problem in the regression models (Fox, 1991). Similarly, the autocorrelation among regression model residuals have been tested using Durbin-Watson factors, if Durbin-Watson (D-
W) factors are between 1 and 3 there is no autocorrelation problem (Alsaeed, 2006). The overall model fit is checked by the F- statistic. All these values are presented along with respective model summary of coefficients and are found not problematic for the models.

\section{FINDINGS AND DISCUSSIONS}

Table 3.1 Descriptive Statistics

\begin{tabular}{|c|c|c|c|c|}
\hline Variables & Min & Max & Mean & SD \\
\hline ROE & -1.5753 & 0.6201 & 0.0938 & 0.5009 \\
\hline STDR & 0.0518 & 0.2901 & 0.1119 & 0.0786 \\
\hline LTDR & 0.0000 & 0.0179 & 0.0059 & 0.0058 \\
\hline TDR & 0.6109 & 0.8564 & 0.7884 & 0.0740 \\
\hline DA & 0.6903 & 1.0510 & 0.9063 & 0.0739 \\
\hline SIZE & 9.2550 & 11.5140 & 10.4219 & 0.5892 \\
\hline GROWTH & 0.0404 & 1.0179 & 0.2416 & 0.2265 \\
\hline
\end{tabular}

The ROE measures the contribution of net income per rupee invested by the firms' stockholders. It is a measure of the efficiency of the owners' invested capital. The average profitability proxied by Return on Equity (ROE) is 9.37 percent. This result reveals that the shareholders of commercial banks in Nepal earned on average 9.37 percent net profit on equity capital. The leverage represented by the average short term debt ratio (STDR) of Nepalese commercial banks is found to be 11.19 percent and this indicates commercial banks are financed (leveraged) with short term debt at approximately Rs.11 per Rs.100 financing whereas long term financing averaged 0.59 percent. This fact attested that the Nepalese commercial banks are highly reluctant in utilizing long term debt in their capital structure. Further, deposit ratio (DR) constitutes the largest portion (78.84 percent) of assets financing and the average total debt assets (DA) ratio is 90.63 percent. The highest debt assets ratio for a bank in a particular year was 105.10 percent and in the same way the minimum ratio for a bank in a year was 69 percent. From the summary of statistics it was observed that 90.63 percent of the total capital of commercial banks in Nepal in the period under study was made up of debt. Of this, 78.84 percent constitute deposit and the remaining was non-deposit liabilities. This result suggests that Nepalese commercial banks are highly levered. The mean of the firms' size which was represented by the natural log of book value of total assets was Rs.10.4219 million with a standard deviation of Rs. 0.5892 million. Total assets for the sample 
banks in the study period were ranged from Rs.9.25 million to Rs.11.51 million. Similarly, the banks' total assets have an average growth rate of 24.16 percent for the ten years of study period. The asset growth ranges approximately from 4 percent (minimum growth rate) to 102 percent (maximum growth rate).

Table 3.2 Correlations Matrix

\begin{tabular}{|c|c|c|c|c|c|c|c|}
\hline Variables & ROE & DA & STDR & LTDR & TDR & SIZE & GROWTH \\
\hline $\mathrm{ROE}$ & 1 & -0.0746 & -0.1715 & 0.4084 & 0.0754 & $0.6029 * *$ & 0.1265 \\
\hline DA & & 1 & $0.5264 *$ & -0.3217 & 0.4644 & 0.2605 & $-0.6053 * *$ \\
\hline STDR & & & 1 & -0.3876 & $-0.5059 *$ & 0.3466 & -0.4263 \\
\hline LTDR & & & & 1 & 0.0110 & 0.1972 & 0.3677 \\
\hline TDR & & & & & 1 & -0.1237 & -0.1809 \\
\hline SIZE & & & & & & 1 & -0.2100 \\
\hline GROWTH & & & & & & & 1 \\
\hline
\end{tabular}

** Correlation is significant at the 0.01 level (2-tailed).

* Correlation is significant at the 0.05 level (2-tailed).

Table 3.2 provides the Pearson correlation for the variables that we used in the regression model. We found that the bank's profitability measured by return on equity is positively correlated with the long term debt and deposit ratio whereas it is negative for short term and total debt. Similarly, there is positive relation size and all types of debt ratios except the deposits. This fact implies that a larger bank tends to use more debt by reducing dependency in deposits. Moreover it was also found that there is significant positive relation between size and profitability and significant negative relation between growth and total debt.
The results show no collinear variables because no correlation exceeds 0.8 as reported in table 3.2. The majority of the correlations correspond to the findings in capital structure literature.

\subsection{Regression Analysis}

The regression coefficients of model (1) were estimated using multiple regressions analysis. Findings from the regression analysis for the selected banks are depicted in Table 3.3.

Table 3.3 Coefficient for Predictors of Profitability and Model Summary 1

\begin{tabular}{|c|c|c|c|c|c|c|c|c|}
\hline \multirow[b]{2}{*}{ Model } & & \multirow[b]{2}{*}{$\mathrm{B}$} & \multirow[b]{2}{*}{$\mathrm{T}$} & \multirow[b]{2}{*}{ Sig. } & \multirow[b]{2}{*}{ VIF } & \multicolumn{3}{|c|}{ Cook's Distance } \\
\hline & & & & & & Min & Max & Mean \\
\hline \multirow{4}{*}{1} & Constant & $-6.4467 * *$ & -3.8006 & 0.002 & & 0.000 & 0.617 & 0.097 \\
\hline & STDR & $-2.4404 *$ & -1.8295 & 0.088 & 1.335 & \multirow{3}{*}{\multicolumn{3}{|c|}{$\begin{array}{l}\mathrm{R}^{2}=0.540 \\
\mathrm{~F}=5.487 \\
\text { Sig. } 0.011 * * \\
\mathrm{D}-\mathrm{W}=1.837\end{array}$}} \\
\hline & SIZE & $0.6475 * *$ & 3.9319 & 0.001 & 1.143 & & & \\
\hline & GROWTH & 0.2726 & 0.6136 & 0.549 & 1.228 & & & \\
\hline
\end{tabular}

** Significant at the 0.05 level

* Significant at the 0.10 level

The $\mathrm{R}$ square measures the extent to which the explanatory variables explain the variations in the dependent variables. The $\mathrm{R}$ square values obtained in Table 3.3 indicate that the explanatory variables explained $54 \%$ of the variations in return on equity in the commercial banks of Nepal within the period under study. The regression coefficient reveals that there is insignificant $(p=0.088>0.05)$ negative relationship between short term debt and return on equity. However the profitability is significantly $(\mathrm{p}=0.001<0.05)$ positively related with control variable of size. Regression model summary 1 tests our first hypothesis and we fail to reject the null hypothesis concluding that there is no relationship between short-term debts and return on equity of Nepalese commercial banks. 
Table 3.4 Coefficient for Predictors of Profitability and Model Summary 2

\begin{tabular}{|c|c|c|c|c|c|c|c|c|}
\hline \multirow[b]{2}{*}{ Model } & & \multirow[b]{2}{*}{ B } & \multirow[b]{2}{*}{$\mathrm{t}$} & \multirow[b]{2}{*}{ Sig. } & \multirow[b]{2}{*}{ VIF } & \multicolumn{3}{|c|}{ Cook's Distance } \\
\hline & & & & & & Min & Max & Mean \\
\hline \multirow{4}{*}{2} & Constant & $-5.362 * *$ & -2.891 & 0.012 & & 0.000 & 0.983 & 0.097 \\
\hline & LTDR & 19.914 & 1.052 & 0.310 & 1.272 & \multirow{3}{*}{$\begin{array}{l}\mathrm{R}^{2}=0.472 \\
\mathrm{~F}=4.176 \\
\text { Sig. } 0.011^{* *} \\
\mathrm{D}-\mathrm{W}=2.67\end{array}$} & & \\
\hline & SIZE & $0.504 * *$ & 2.844 & 0.013 & 1.151 & & & \\
\hline & GROWTH & 0.3677 & 0.757 & 0.462 & 1.279 & & & \\
\hline
\end{tabular}

** Significant at the 0.05 level

The $\mathrm{R}$ square values obtained in Table 3.4 indicate that the explanatory variables (Long term debt, size and growth) explained 47.2 percent of the variations in return on equity in the commercial banks of Nepal within the period under study. The regression coefficient reveals that there is insignificant $(p=0.3105>0.05)$ positive relationship between long term debt and return on equity. However the profitability significantly $(\mathrm{p}=0.0130<0.05)$ positively related with control variable of size. Regression model summary 2 tests our second hypothesis and we fail to reject the null hypothesis concluding that there is no relationship between long-term debts and return on equity of Nepalese commercial banks.

Table 3.5 Coefficient for Predictors of Profitability and Model Summary 3

\begin{tabular}{|c|c|c|c|c|c|c|c|c|}
\hline \multirow[b]{2}{*}{ Model } & & \multirow[b]{2}{*}{ B } & \multirow[b]{2}{*}{$\mathrm{t}$} & \multirow[b]{2}{*}{ Sig. } & \multirow[b]{2}{*}{ VIF } & \multicolumn{3}{|c|}{ Cook's Distance } \\
\hline & & & & & & Min & Max & Mean \\
\hline \multirow{4}{*}{3} & Constant & -7.3983 & -3.2742 & 0.0055 & & 0.000 & 0.732 & 0.141 \\
\hline & DR & 1.4760 & 1.0913 & 0.2936 & 1.0640 & \multirow{3}{*}{\multicolumn{3}{|c|}{$\begin{array}{l}\mathrm{R}^{2}=0.475 \\
\mathrm{~F}=4.225 \\
\text { Sig. } 0.025^{* *} \\
\mathrm{D}-\mathrm{W}=2.78\end{array}$}} \\
\hline & SIZE & 0.5912 & 3.4615 & 0.0038 & 1.0766 & & & \\
\hline & GROWTH & 0.6902 & 1.5396 & 0.1460 & 1.0960 & & & \\
\hline
\end{tabular}

** Significant at the 0.05 level

The $\mathrm{R}$ square values obtained in Table 3.5 showed that the explanatory variables (deposit ratio, size and growth) explained 47.5 percent of the variations in return on equity in the commercial banks of Nepal within the period under study. The regression coefficient reveals that there is insignificant $(p=0.2936>0.05)$ positive relationship between deposit capital and return on equity. However the ROE significantly $(\mathrm{p}=0.0038<0.05)$ positively related with control variable of size. Regression model summary 3 tests our third hypothesis and we fail to reject the null hypothesis concluding that there is no relationship between deposit ratio and return on equity of Nepalese commercial banks.

Table 3.6 Coefficient for Predictors of Profitability and Model Summary 4

\begin{tabular}{|c|c|c|c|c|c|c|c|c|}
\hline \multirow[b]{2}{*}{ Model } & & \multirow[b]{2}{*}{ B } & \multirow[b]{2}{*}{$\mathrm{t}$} & \multirow[b]{2}{*}{ Sig. } & \multirow[b]{2}{*}{ VIF } & \multicolumn{3}{|c|}{ Cook's Distance } \\
\hline & & & & & & Min & Max & Mean \\
\hline \multirow{4}{*}{4} & Constant & $-5.1551 * *$ & -2.2747 & 0.0392 & & 0.000 & 0.732 & 0.141 \\
\hline & TDR & -0.9457 & -0.5483 & 0.5921 & 1.6279 & \multirow{2}{*}{\multicolumn{3}{|c|}{$\begin{array}{l}\mathrm{R}^{2}=0.443 \\
\mathrm{~F}=3.70 \\
\text { Sig. } 0.0378 * *\end{array}$}} \\
\hline & SIZE & $0.5764 * *$ & 3.2726 & 0.0056 & 1.0778 & & & \\
\hline & GROWTH & 0.4078 & 0.7334 & 0.4754 & 1.5875 & $\mathrm{D}-\mathrm{W}=2.51$ & & \\
\hline
\end{tabular}

** Significant at the 0.05 level

The $\mathrm{R}$ square values obtained in Table 3.6showed that the explanatory variables (total debt, size and growth) explained 44.3 percent of the variations in return on equity in the commercial banks of Nepal within the period under study. The regression coefficient reveals that there is insignificant ( $\mathrm{p}=0.5921>0.05)$ negative relationship between total debt ratio and return on equity. However the ROE significantly $(p=0.0056<0.05)$ positively related with control variable of size. Regression model summary 4 tests our third hypothesis and we fail to reject the null hypothesis concluding that there is no relationship between total debt and return on equity of Nepalese commercial banks. 


\section{CONCLUSION}

This paper examined the relationship of profitability and capital structure of commercial banks in Nepal. The empirical analysis was conducted using multiple regression models by taking return on equity as dependent variables to proxy the profitability while short term debt, long term debt, deposits and total leverage were the independent variables as proxy of capital structure or leverage. Bank size and their asset growth were used as control variables. This empirical analysis reveals that Nepalese commercial banks are highly levered with deposits constituting the largest portion of leverage followed by short term debt whereas the long term debt is the least. More than 40 percent bank profitability measured by return on equity is predicted by the explanatory -capital structure variables. Similarly, it is also revealed that return on equity is insignificantly positively related with long term debt and deposits whereas it is insignificant negative with short term debt and total debt. In all regression models, profitability is significantly positively related with banks size indicating that larger the size of the bank higher is the return for shareholders. Based on the findings of hypothesis test where we failed to reject null hypothesis, it can be concluded that capital structure issue is not statistically significant in determining the profitability of commercial banks in Nepal. This study contributes to the literature by estimating a panel data model of profitability and capital structure for the Nepalese banking sector that presents some useful information for the important role of leverage in profitability, it leaves a room for future research to find out the major determinants of leverage by considering both bank as well economy specific variables by including other development banks and finance companies.

\section{REFERENCES}

1. Abor J. (2005). The effect of capital structure on profitability: empirical analysis of listed firm in Ghana. Journal of Risk Finance, 6(5),438-445. https://doi.org/10.1108/15265940510633505

2. Alsaeed, K. (2006). The association between firm-specific characteristics and disclosure: The case of Saudi Arabia. Managerial Auditing Journal, 21(5), 476-496. https://doi.org/10.1108/02686900610667256

3. Amidu, M. (2007). Determinants of capital structure of banks of Ghana: an empirical approach. Baltic Journal of Management, 2(1),6779. https://doi.org/10.1108/17465260710720255

4. Baral, K. (2004). Determinants of capital structure: a case study of listed companies of Nepal. The Journal of Nepalese Business Studies, 1(1), 1-13. https://doi.org/10.3126/jnbs.v1i1.34.

5. Barclay, M. \& Smith, C. (2005). The capital structure puzzle: the evidence revisited. Journal of Applied Corporate Finance, 17,(1), 8-17. https://doi.org/10.1111/j.1745-6622.2005.012_2.x
6. Buser, S.A., Chen, A.H. \& Kane, E.J. (1981). Federal deposit insurance, regulatory policy and optimal bank capital. Journal of Finance 35, 51-60. https://doi.org/10.1111/j.15406261.1981.tb03534.x

7. Caesar, G., \& Holmes, S. (2003). Capital structure and financing of SMEs: Australian evidence. Journal of Accounting and Finance 43(2), 123-147. 10.1111/1467-629X.t01-1-00085

8. Fama, E.F. \& French, K.R. (1998). Taxes, financing decisions, and firm value. Journal of Finance, 53(3), 819-943.

https://doi.org/10.1111/0022-1082.00036.

9. Fox, J. (1991). Regression diagnostics. Thousand oaks', CA: Stage publication, Qualitative applications in the social sciences, 79. https://dx.doi.org/10.4135/9781412985604

10. Gajurel, D. P.(2005). Capital structure management in Nepalese enterprises. Master's Degree Thesis, Kathmandu: Faculty of Management, Tribhuvan University.

11. Gill, A., Nahum, B. \& Mathur, N. (2011). The effect of capital structure on profitability: evidence from the United States. International Journal of Management, 28(4),1,3-15.

https://www.researchgate.net/publication/28100454 0

12. Graham, J.R. (2000). How big are the tax benefits of debt? Journal of Finance, 55, pp. 1901-41. 10.1111/0022-1082.00277

13. Grossman, S. J. \& Hart, O.D. (1983). Corporate financial structure and managerial incentives. Economics of Information and Uncertainty, University of Chicago Press, 259-298.

https://ssrn.com/abstract=578641

14. Hall, G. C., Hutchinson, P. J. \& Michaelas, N. (2004). Determinants of the capital structures of European SMEs. Journal of Business Finance \& Accounting, 31(5, 6), 711-728. 10.1111/j.0306686X.2004.00554.X

15. Hirshleifer, J. (1966). Investment decision under uncertainty: application of the state performance approach. Quarterly Journal of Economics, 80(2), 252-277. $10.2307 / 1880692$

16. KC, B.K. (1994). The financing of corporate growth: a case study of Nepal. Doctoral Thesis, New Delhi: University of Delhi.

17. Kester, W.C. (1986). Capital and ownership structure: a comparison of United States and Japanese manufacturing corporations. Financial Management, 15 (1), 5-16.

https://scirp.org/reference/referencespapers.aspx?re ferenceid $=779129$

18. Khan, M.Y. \& Jain, P.K. (1997). Financial management. Tata McGraw Hill Publishing 
Company Limited, New Delhi, ( $2^{\text {nd }}$ ed.), 473, 517518.

19. Modigliani, F. \& Miller, M. H. (1958). The cost of capital, corporation finance and the theory of investment. The American Economic Review, 48(3), 261-297.

https://gvpesquisa.fgv.br/sites/gvpesquisa.fgv.br/fil es/arquivos/terra_-

_the_cost_of_capital_corporation_finance.pdf

20. Modigliani, F. \& Miller, M. H. (1963). Corporate income taxes and the cost of capital: a correction. The American Economic Review, 53(3), 433-443.

21. https://www.scirp.org/(S(i43dyn45teexjx455qlt3d2 q))/reference/ReferencesPapers.aspx?ReferenceID= 1363843

22. Myers, S.C., Majluf, N.S. (1984). Corporate financing and investment decisions when firms have information that investors do not. Journal of Financial Economics, 13(2), 187-221. https://doi.org/10.1016/0304-405X(84)90023-0

23. Najjar, N., \& Petrov, K. (2011). Capital structure of insurance companies in Bahrain. International Journal of Business and Management, 6(11), 138142. $10.5539 /$ ijbm.v6n11p138

24. Ooi, J. (1999). The determinants of capital structure: evidence on UK property companies. Journal of Property Investment \& Finance, 17(5), 464-480. https://doi.org/10.1108/14635789910294886.

25. Petersen, M. \& Rajan, R. (1994a). The benefits of lending relationships: evidence from small business data. Journal of Finance, 49(1), 3-37. https://doi.org/10.1111/j.15406261.1994.tb04418.x

26. Pradhan, R.S. \& Ang, J.S. (1994). A comparison of financial management practices in Nepal among government-owned, publicly-traded and privatively-held firms. Studies in the Financial Markets of the Pacific Basin, 11, 139-163.

27. Rajan, R. G. \& Zingale, L. (1995). What do we know about capital structure? Some evidences from international data. Journal of Finance, 50(5), 1421-
1460. https://doi.org/10.1111/j.1540-6261.1995. tb05184.X

28. Ross, S. (1977). The determination of financial structure: an incentive signaling approach. The Bell Journal of Economics, 8(1), 23-40. http://links.jstor.org/sici?sici=0361-915X\%2819 7721\%298\%3A1\%3C23\%3ATDOFST\%3E2.0.CO \%3B2-Q

29. Saunders, M., Lewis, P. and Thornhill, A. (2007). Research Methods for Business Students, (4 ${ }^{\text {th }}$ ed.) Prentice Hall, UK.

30. Shrestha, M.K. (1985). Analysis of capital structure in selected public enterprises. Nepalese Journal of Public Administration, 16(2), 41-57.

31. Shubita, M.\& Jaafer, A. (2012).The relationship between capital structure and profitability. International Journal of Business and Social Science, 3(15), 105-112.

https://www.researchgate.net/publication/33731755 0_The_Relationship_between_Capital_Structure_a nd_Profitability

32. Stiglitz, J. (1969). A re-examination of M-M theorem. American Economic Review, 59(5),784793. https://www.jstor.org/stable/1810676

33. Taub, A.J. (1975). Determinants of the firm's capital structure. Review of Economics and Statistics, 57(4),410-416.

https://www.jstor.org/stable/1935900

34. Titman, S. \& Wessels, R. (1988). The determinants of capital structure choice. Journal of Finance, 43(1), 1-19. https://doi.org/10.1111/j.15406261.1988.tb02585.x

35. Wang, H. (2010). Capital structure and corporate performance: evidences from Chinese small and medium-sized firms. IEEE, 1-4.

10.1109/ICEEE.2010.5660487

36. Watson, D. and Head, A. (2007). Corporate Finance-Principles and Practices. (4 ${ }^{\text {th }}$ ed.), FT Prentice Hall, UK. 


\section{Appendix 1}

Normality Test for regression model 1

Histogram

Dependent Variable: ROE

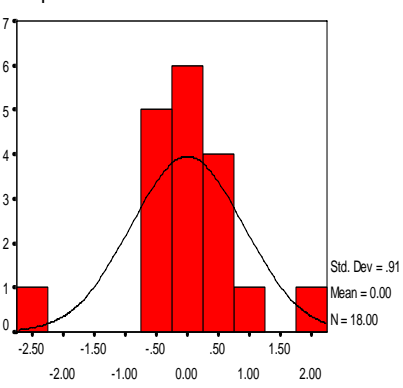

Regression Standardized Residual

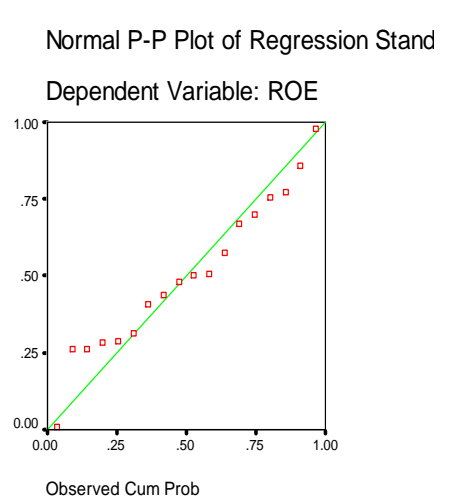

Observed Cum Prob
Scatterplot

Dependent Variable: ROE

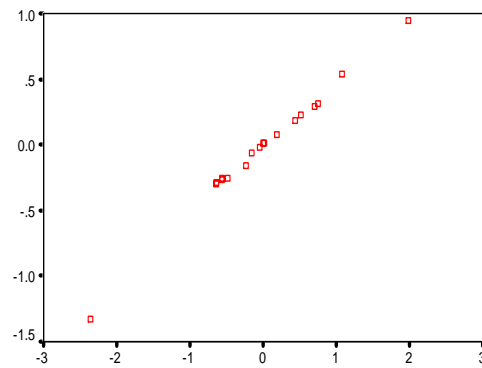

Regression Standardized Residual

Normality Test for regression model 2

Histogram

Dependent Variable: ROE

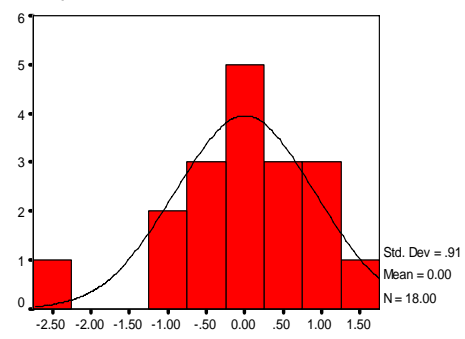

Regression Standardized Residual
Normal P-P Plot of Regression Stand

Dependent Variable: ROE

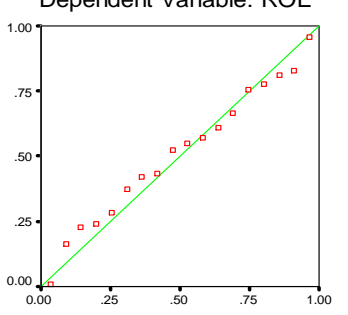

Observed Cum Prob
Scatterplot

Dependent Variable: ROE

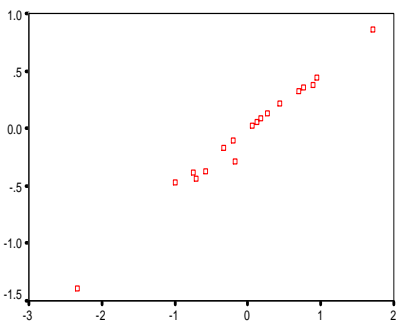

Regression Standardized Residual

Normality Test for regression model 3

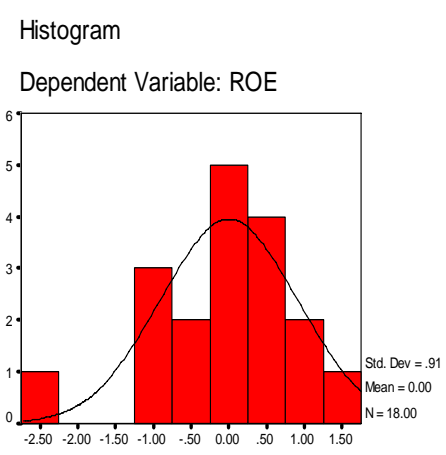

Normal P-P Plot of Regression Stand

Dependent Variable: ROE

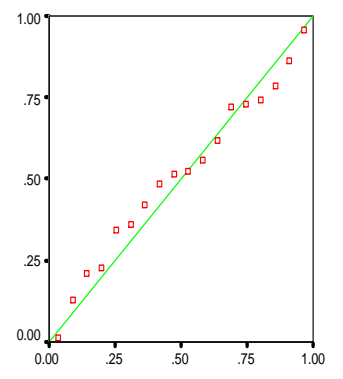

Observed Cum Prob

Scatterplot

Dependent Variable: ROE

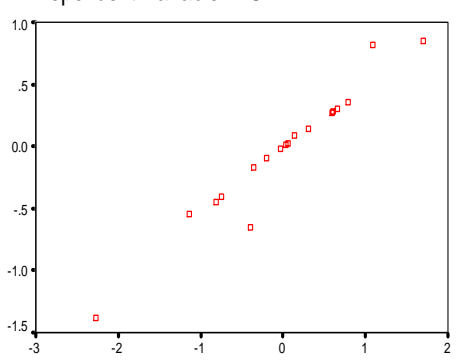

Regression Standardized Residual

Normality Test for regression model 4

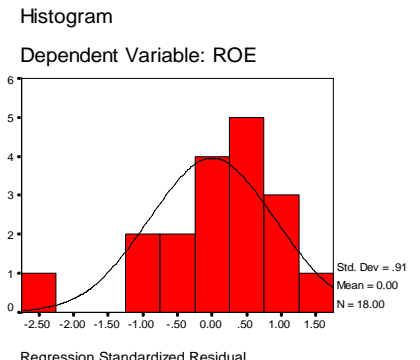

Normal P-P Plot of Regression Stand

Dependent Variable: ROE

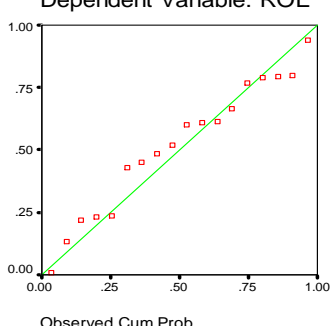

Scatterplot

Dependent Variable: ROE

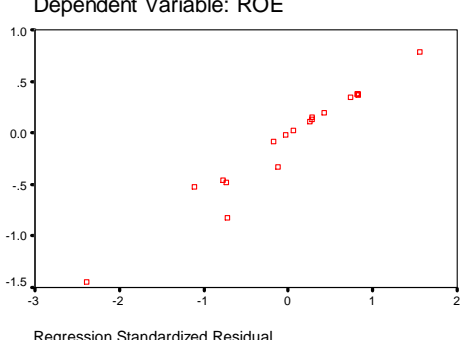

